\title{
The increasing of superoxide dismutase (SOD) in metabolic syndrome rats by robusta coffee leaves (Coffea canephora)
}

\author{
${ }^{1}$ Almira, V.G., ${ }^{1,2 *}$ Widyastuti, N., ${ }^{1,2}$ Anjani, G., ${ }^{3}$ Widyastiti, N.S., ${ }^{1,2}$ Panunggal, B., \\ ${ }^{1,2}$ Nissa, C., ${ }^{1,2}$ Tsani, A.F.A., ${ }^{1,2}$ Wijayanti, H.S. and ${ }^{1,2}$ Purwanti, R. \\ ${ }^{I}$ Department of Nutrition Science, Faculty of Medicine, Universitas Diponegoro, Jl. Prof H. Soedarto, SH, \\ Tembalang, Semarang 50275, Indonesia \\ ${ }^{2}$ Center of Nutrition Research (CENURE), Universitas Diponegoro, Jl. Prof H. Soedarto, SH, Tembalang, \\ Semarang 50275, Indonesia \\ ${ }^{3}$ Department of Clinical Pathology, Faculty of Medicine, Universitas Diponegoro, Jl. Prof H. Soedarto, SH, \\ Tembalang, Semarang 50275, Indonesia
}

Article history:

Received: 29 December 2019

Received in revised form: 4

February 2020

Accepted: 6 February 2020

Available Online: 30 May 2020

\section{Keywords:}

Superoxide dismutase, Antioxidant,

Metabolic syndrome,

Robusta coffee leaves

\section{DOI:}

https://doi.org/10.26656/fr.2017.4(S3).S10

\begin{abstract}
Metabolic syndrome is a group of symptoms with obesity as the main determinant. Obesity increases oxidative stress which results in an imbalance between free radicals and antioxidants. Robusta coffee leaves are a source of antioxidants that can increase antioxidant levels in the body. The study was conducted to prove the effect of Robusta coffee leaves on the activity of superoxide dismutase (SOD) in metabolic syndrome rats. An experimental study of randomized pre-post test with control group design was conducted on 36 male Wistar rats. The rats besides the control group 1 were fed with high fat-fructose diet (HFFD) for 14 days. Samples were divided into 6 groups, each of 6 rats: control group 1 healthy rat without treatment (K1), control group 2 rats without treatment (K2), rats were given $20 \mathrm{mg} / \mathrm{kg}$ of mangiferin (X1), groups $\mathrm{X} 2, \mathrm{X} 3$, and $\mathrm{X} 4$ were given Robusta coffee leaves with each of dose is $0.09 \mathrm{~g} / 200 \mathrm{~g} \mathrm{BW}, 0.18 \mathrm{~g} / 200 \mathrm{~g} \mathrm{BW}$ and 0.36 $\mathrm{g} / 200 \mathrm{gBW}$. Each dose of coffee leaves was steeped with $3.6 \mathrm{~mL}$ of water at $70^{\circ} \mathrm{C}$ for 10 mins. The intervention was given for 28 days. The metabolic syndrome was achieved with blood glucose level 131.14-132.70 mg/dL, triglycerides 153.49-157.18 mg/dL, and HDL $24.59-26.22 \mathrm{mg} / \mathrm{dL}$. The highest increased in SOD levels in group X4 $(35.78 \pm 8.27 \mathrm{u} / \mathrm{mL})$ $(p=0.000)$. The intervention of Robusta coffee leaves $0.36 \mathrm{~g} / 200 \mathrm{~g} \mathrm{BW}$ is the most effective dose in increasing SOD levels in metabolic syndrome rats.
\end{abstract}

\section{Introduction}

Metabolic syndrome is a cluster of conditions including obesity, dyslipidemia, hyperglycemia, and high blood pressure (Lam and LeRoith, 2019). Based on National Cholesterol Education Program which is modified for the Asian region define metabolic syndrome as having three or more of conditions, such as waist circumference of more than $90 \mathrm{~cm}$ in men and more than $80 \mathrm{~cm}$ in women; triglyceride level over 150 $\mathrm{mg} / \mathrm{dL}$; high-density lipoprotein (HDL) less than $45 \mathrm{mg} /$ $\mathrm{dL}$ for men and less than $50 \mathrm{mg} / \mathrm{dL}$ for women; blood pressure of 130/85 mmHg or higher; and fasting glucose level more than $110 \mathrm{mg} / \mathrm{dL}$ (Kaur, 2014).

The prevalence of metabolic syndrome in the world is between $10 \%$ and $84 \%$ based on ethnicity, age, gender, and race. The prevalence of metabolic syndrome in
America in 2000 was about 47 million adult population. From 1988-1994 to 2007-2012, the prevalence of metabolic syndrome in America increased from 25.3\% to $34.2 \%$ in adults aged 18 years or older (Moore et al., 2017). In China, the incidence of metabolic syndrome increased by 37\% during 2001-2009 (Guo et al., 2017). The prevalence of metabolic syndrome in Indonesia increased by $23 \%$ in 2005 (Suhaema and Masthalina, 2015).

Obesity is a major determinant of metabolic syndrome. Obesity is associated with systemic inflammation in adipose tissue which increases proinflammatory status and oxidative stress (Marseglia et al., 2014). Oxidative stress occurs because of an imbalance between free radicals and antioxidants in the body. Free radicals are atoms or molecules that have unpaired electrons. Free radicals are divided into two 
categories, Reactive Oxygen Species (ROS) and Reactive Nitrogen Species (RNS). Reactive Oxygen Species (ROS) are reactive oxygen that is physiologically formed in cells as a by-product of cell metabolism. Oxidative damage is more prone to occur in obese people because of decreased sources of antioxidants in the body (Widayati, 2012; Marseglia et al., 2014).

Superoxide dismutase (SOD), catalase, and glutathione peroxidase (GPx) are endogenous antioxidants that act as ROS scavengers (Incalza et al., 2018). Superoxide dismutase (SOD) is the most powerful antioxidant in cells that acts as the main defense against free radicals (Ighodaro and Akinloye, 2018). When endogenous antioxidants are inadequate to eliminate ROS from the body, the body needs exogenous antioxidants, antioxidants derived from food (Mirończuk -Chodakowska et al., 2018). One of the food ingredients that contain antioxidants is coffee leaves (Huyut et al., 2017).

Coffee leaves have been consumed by people in Sumatra as a tea beverage, known as "Kawa Daun" or "Kopi Kawa" (Rasyid et al., 2013). Coffee leaves contain various phytochemicals, including alkaloids, flavonoids, terpenoids, amino acids, sucrose, tannins, xantonoids, phenolic acids, and catechins that function as anti-inflammatory, antidiabetic, antihyperlipidemic, antioxidant, antimicrobial, and neuroprotective which can control oxidative stress (Chen et al., 2018).

The most widely cultivated coffee plants in Indonesia is Robusta coffee (Coffea canephora) (Kanisius, 1988). Previous research describes the ethanolic extract of Robusta coffee leaves has an antioxidant activity with $\mathrm{IC}_{50}$ value of $10.68 \mathrm{mg} / \mathrm{mL}$. Ethanolic extract of Robusta coffee in mice with Type 2 Diabetes Mellitus by high fat and sucrose diet can lower blood glucose levels (Shiyan et al., 2017). Provision of $5 \%$ Robusta coffee leaves infusion can reduce blood glucose levels in alloxan-induced rats (Purwaningsih, 2014).

Brewed Robusta coffee leaves are known to become a traditional drink by people in several regions in Indonesia. The content in Robusta coffee leaves contains phytochemical compounds that make Robusta coffee leaves into food material that can be used as a source of antioxidants. The aim of this study was to examine the effect of brewed Robusta coffee leaves on SOD levels in metabolic syndrome rats.

\section{Materials and methods}

\subsection{Materials}

The Robusta coffee leaves were hand-picked from Mekarsari Village, Pasir Jambu District, Bandung Regency, West Java, Indonesia.

\subsection{Methods}

All experiments were approved by The Ethical Committee of Medical Research of Faculty of Medicine, Universitas Diponegoro (No. 16/EC/H/FK-UNDIP/ III/2019). This study was a randomized pre-posttest with control group design. The study was conducted in March -May 2019 in Centre for Food and Nutrition of Gajah Mada University, Yogyakarta-Indonesia (Pusat Studi Pangan dan Gizi Universitas Gajah Mada, YogyakartaIndonesia) for the maintenance of rats and examination of SOD levels. The Tea and Quinine Research Center Gambung, Bandung-Indonesia (Pusat Penelitian Teh dan Kina Gambung, Bandung-Indonesia) for manufacturing brewed Robusta coffee leaves products.

The Robusta coffee leaves were processed as Japanese style Green Tea Process (JGTP). The leaves were blanched in boiling water at $100^{\circ} \mathrm{C}$ for $75 \mathrm{~s}$, then dipped in water. Coffee leaves were drained and cooled, and the midrib removed. Furthermore, the coffee leaves were crushed three times using a Crushing Tearing and Curling (CTC) machine. The coffee leaves that have been crushed were dried using a rack drier at $80^{\circ} \mathrm{C}$ for 45 hrs. Coffee leaves were processed in a mini-processing green tea processing laboratory in The Tea Quality Processing and Testing Laboratory in The Tea and Quinine Research Center Gambung, Bandung-Indonesia (Atmaja et al., 2018).

Thirty-six male Wistar rats (6 weeks old and 150200 g body weight) were randomLy divided into 6 groups of 6 rats in each group after a week of adaptation. All rats were housed individually. The rats were all fed with a standard chow (Comfeed II) $20 \mathrm{~g} /$ day and drink ad libitum. The rats besides the control group 1 were fed with high fat-fructose diet (HFFD), contains pork oil $(20 \%)$, cholesterol $(1.5 \%)$, cholic acid $(0.5 \%)$ and a standard chow $(80 \%)$ given orally, while fructose of 1 $\mathrm{mL} / 200 \mathrm{gBW}$ is given through sonde for 14 days.

Rats were conditioned into metabolic syndrome with blood glucose $\geq 110 \mathrm{mg} / \mathrm{dL}$, triglycerides $>150 \mathrm{mg} / \mathrm{dL}$ and HDL $<40 \mathrm{mg} / \mathrm{dL}$ (Rochlani et al., 2017; Saifur Rohman et al., 2017). The control group 1 healthy rats without treatment (K1), control group 2 metabolic syndrome rats without treatment (K2), metabolic syndrome rats were given $20 \mathrm{mg} / \mathrm{kg}$ of mangiferin (X1), groups $\mathrm{X} 2, \mathrm{X} 3$, and $\mathrm{X} 4$ metabolic syndrome rats were given Robusta coffee leaves with each of dose is 0.09 
$\mathrm{g} / 200 \mathrm{gBW}, 0.18 \mathrm{~g} / 200 \mathrm{gBW}$ and $0.36 \mathrm{~g} / 200 \mathrm{gBW}$. Each dose of coffee leaves was brewed with $3.6 \mathrm{~mL}$ of water at $70^{\circ} \mathrm{C}$ for 10 mins. The intervention was given for 28 days.

Measurement of blood glucose, triglycerides, and HDL as determinants of metabolic syndrome criteria in rats was carried out after 14 days of HFFD administration. Measurement of rat body weight was done once a week and measurements of SOD levels were carried out before and after the intervention. Examination of SOD levels uses the Enzyme-Linked Immunosorbent Assay (ELISA) method by taking blood serum in the retro-orbital plexus.

\subsection{Data analysis}

The results were expressed in mean \pm standard deviation (SD) and some in the median (minimummaximum). The normality of the study was tested using the Kolmogorov-Smirnov test. Paired t-test and one-way analysis of variance (ANOVA) were used for parametric results; differences between the groups were evaluated by post-hoc test. Wilcoxon test, Kruskal Wallis, and Mann-Whitney were used for non-parametric results.

\section{Results}

\subsection{Characteristics of subject}

High fat-fructose diet administration for 14 days increased blood glucose $\geq 110 \mathrm{mg} / \mathrm{dL}$, triglycerides $>150$ $\mathrm{mg} / \mathrm{dL}$ and decrease HDL $<40 \mathrm{mg} / \mathrm{dL}$. The conditioning of rats into metabolic syndrome was achieved with blood glucose 131.14-132.70 mg/dL, triglyceride 153.59$157.18 \mathrm{mg} / \mathrm{dL}$ and $24.59-2.22 \mathrm{mg} / \mathrm{dL}$ as in Table 1 .
3.2 Characteristics of body weight before and after brewed Robusta coffee leaves treatment

Rats body weights were significantly increased in all groups $(p<0.000)$. There was a significant difference in body weight between groups before treatment and after treatment $(p=0.000)$. X2 group increased body weight $(28.16 \pm 0.71 \mathrm{~g})$ higher than X3 $(25.58 \pm 2.35 \mathrm{~g})$ and $\mathrm{X} 4$ $(23.45 \pm 1.39 \mathrm{~g})$ groups as shown in Table 2 .

\subsection{Superoxide dismutase (SOD) levels before and after brewed Robusta coffee leaves treatment}

There were significantly increased on SOD levels in mangiferin treatment group (X1) $(p=0.000), 0.18 \mathrm{~g} / 200$ g/BW Robusta coffee leaves treatment group (X3) ( $p=0.000$ ), and $0.36 \mathrm{~g} / 200 \mathrm{~g} \mathrm{BW}$ Robusta coffee leaves treatment group (X4) $(p=0.000)$. SOD levels between groups before treatment and after treatment were significantly different. X4 group with $0.36 \mathrm{~g} / 200 \mathrm{~g} \mathrm{BW}$ Robusta coffee leaves increased SOD levels $(35.78 \pm 8.27$ $\mathrm{u} / \mathrm{mL})$ higher than $\mathrm{X} 2(6.86 \pm 7.63 \mathrm{u} / \mathrm{mL})$ and $\mathrm{X} 3$ $(19.30 \pm 5.76 \mathrm{u} / \mathrm{mL})$ groups. X1 group with mangiferin treatment had increased SOD levels $(35.40 \pm 8.33 \mathrm{u} / \mathrm{mL})$ almost the same as $\mathrm{X} 4$ group as seen in Table 3 .

\section{Discussion}

This study showed that HFFD administration increase in body weight, blood glucose, triglycerides, and decreased HDL. Previous studies have explained that HFFD administration can induce weight gain, glucose intolerance, and leptin intolerance (Jarukamjorn et al., 2016). HFFD administration in rats for 14 days can result in hyperglycemia and dyslipidemia (Octavia et al., 2017)

Table 1. Characteristics of subject after high fat-fructose diet (HFFD) administration

\begin{tabular}{ccccc}
\hline Groups & Body Weight $(\mathrm{g})$ & Blood Glucose $(\mathrm{mg} / \mathrm{dL})$ & Triglyceride $(\mathrm{mg} / \mathrm{dL})$ & HDL $(\mathrm{mg} / \mathrm{dL})$ \\
\hline K1 & $180.50 \pm 3.06^{1}$ & $71.29 \pm 1.53^{1}$ & $68.77 \pm 5.97^{1}$ & $86.36 \pm 2.28^{1}$ \\
K2 & $189.91 \pm 2.08^{1}$ & $132.70 \pm 1.48^{1}$ & $157.18 \pm 4.88^{1}$ & $25.05 \pm 1.84^{1}$ \\
X1 & $191.25 \pm 5.59^{1}$ & $131.81 \pm 1.88^{1}$ & $153.75 \pm 3.11^{1}$ & $26.22 \pm 1.69^{1}$ \\
X2 & $190.66 \pm 3.64^{1}$ & $131.56 \pm 2.57^{1}$ & $156.12 \pm 2.48^{1}$ & $26.22 \pm 1.30^{1}$ \\
X3 & $192.50(184-195.5)^{2}$ & $131.14 \pm 2.13^{1}$ & $153.49 \pm 1.96^{1}$ & $26.22 \pm 2.15^{1}$ \\
X4 & $195.66 \pm 3.01^{1}$ & $132.53 \pm 2.36^{1}$ & $156.12 \pm 2.77^{1}$ & $24.59 \pm 1.99^{1}$ \\
\hline
\end{tabular}

${ }^{1}$ Mean \pm SD, ${ }^{2}$ Median (minimum-maximum)

Table 2. Characteristics of body weight before and after brewed Robusta coffee leaves treatment

\begin{tabular}{ccccc}
\hline \multirow{2}{*}{ Groups } & \multicolumn{3}{c}{ Body Weight $(\mathrm{g})$} & $\mathrm{p}$ \\
\cline { 2 - 4 } & Before Treatment & After Treatment & Delta & 0 \\
K1 & $180.50 \pm 3.06^{1, \mathrm{a}}$ & $198.75 \pm 2.81^{1, \mathrm{a}}$ & $18.25 \pm 1.16^{1, \mathrm{a}}$ & 0 \\
K2 & $189.91 \pm 2.08^{1, \mathrm{~b}}$ & $224.12 \pm 2.11^{1, \mathrm{c}}$ & $34.20 \pm 1.08^{1, \mathrm{~b}}$ & 0 \\
X1 & $191.25 \pm 5.59^{1, \mathrm{~b}}$ & $212.25 \pm 5.94^{1 \mathrm{~b}}$ & $20.12(20-24)^{2, \mathrm{c}}$ & 0 \\
X2 & $190.66 \pm 3.64^{1, \mathrm{~b}}$ & $218.83 \pm 3.62^{1, \mathrm{~b}, \mathrm{c}}$ & $28.16 \pm 0.71^{1, \mathrm{~d}}$ & 0.028 \\
X3 & $192.50(184-195.5)^{2, \mathrm{~b}}$ & $217.33 \pm 4.66^{1, \mathrm{~b}, \mathrm{c}}$ & $25.58 \pm 2.35^{1, \mathrm{~d}, \mathrm{e}}$ & 0 \\
X4 & $195.66 \pm 3.01^{1, \mathrm{~b}}$ & $219.12 \pm 4.11^{1, \mathrm{~b}, \mathrm{c}}$ & $23.45 \pm 1.39^{1, \mathrm{c}, \mathrm{e}}$ & 0 \\
$\mathrm{p}$ & $0.001^{*}$ & $0.000^{*}$ & $0.000^{*}$ & \\
\hline
\end{tabular}

${ }^{1}$ Mean \pm SD,${ }^{2}$ Median (minimum-maximum) $*$ Significant $(\mathrm{p}=<0.05){ }^{\mathrm{a}, \mathrm{b}, \mathrm{c}, \mathrm{d}, \mathrm{e}}$ Post Hoc Test 
Table 3. Superoxide Dismutase (SOD) before and after brewed Robusta coffee leaves treatment

\begin{tabular}{ccccc}
\hline \multirow{2}{*}{ Groups } & \multicolumn{3}{c}{ SOD Levels $(\mathrm{u} / \mathrm{mL})$} & \multirow{2}{*}{$\mathrm{p}$} \\
\cline { 2 - 4 } & Before Treatment & After Treatment & Delta & \\
\hline K1 & $79.41 \pm 3.66^{1, \mathrm{a}}$ & $78.70 \pm 3.46^{1, \mathrm{a}}$ & $0.70 \pm 1.22^{1, \mathrm{a}, \mathrm{b}}$ & 0.216 \\
$\mathrm{~K} 2$ & $25.49 \pm 6.32^{1, \mathrm{~b}}$ & $19.44 \pm 4.49^{1, \mathrm{~b}}$ & $-2.99\left(-22.33-(-1.20)^{2, \mathrm{~b}}\right.$ & 0.128 \\
X1 & $29.41 \pm 4.63^{1, \mathrm{~b}}$ & $64.81 \pm 4.82^{1, \mathrm{e}}$ & $35.40 \pm 8.33^{1, \mathrm{e}}$ & 0.000 \\
X2 & $26.47 \pm 3.66^{1, \mathrm{~b}}$ & $33.33 \pm 5.23^{1, \mathrm{c}}$ & $6.86 \pm 7.63^{1, \mathrm{c}}$ & 0.079 \\
X3 & $24.83 \pm 6.40^{1, \mathrm{~b}}$ & $44.13 \pm 5.15^{1, \mathrm{~d}}$ & $19.30 \pm 5.76^{1, \mathrm{~d}}$ & 0.000 \\
X4 & $22.55 \pm 6.41^{1, \mathrm{~b}}$ & $58.33 \pm 3.46^{1, \mathrm{e}}$ & $35.78 \pm 8.27^{1, \mathrm{e}}$ & 0.000 \\
p & $0.000^{*}$ & $0.000^{*}$ & $0.000^{*}$ & \\
\hline
\end{tabular}

${ }^{1}$ Mean \pm SD, ${ }^{2}$ Median (minimum-maximum) ${ }^{*}$ Significant $(\mathrm{p}=<0.05){ }^{\mathrm{a}, \mathrm{b}, \mathrm{c}, \mathrm{d}, \mathrm{e}}$ Post Hoc Test

High-fructose diet results in the accumulation of triglycerides and cholesterol which causes a decrease in insulin sensitivity, insulin resistance, and glucose intolerance (Wong et al., 2016). Previous studies have explained that fructose diet results in an increase in body weight in mice (Jürgens et al., 2005). High-fat diet results in an increase in body mass, triglycerides, and LDL (Fraulob et al., 2010).

Brewed Robusta coffee leaves were processed using the Japanese style Green Tea Process (JGTP) method. This process maintains the phytochemical content in coffee leaves. Previous studies have explained that the JGTP method in Arabica coffee leaves has a higher phytochemical concentration compared to other methods (Chen et al., 2018).

After the intervention, body weight showed a significant increased between groups before and after treatment. In the $\mathrm{K} 1$ group, healthy rats were only given standard chow and drink experienced an increase in body weight. Weight gain in the treatment group was lower than in the K2 group. Rats with a dose of $0.36 \mathrm{~g} / 200 \mathrm{~g}$ BW of Robusta coffee leaves experienced the lowest weight gain compared with a dose of $0.09 \mathrm{~g} / 200 \mathrm{~g} \mathrm{BW}$ and $0.18 \mathrm{~g} / 200 \mathrm{~g} \mathrm{BW}$ of Robusta coffee leaves. The higher the doses administered, the lower was the increase in body weight of rats. This relates to the antioxidant content in Robusta coffee leaves which can reduce weight gain. Antioxidants that may be present in Robusta coffee leaves are alkaloids, flavonoids, xantonoids, and phenolics (Chen et al., 2018).

Based on previous research, the administration of flavonoids can maintain body weight and reduce the absorption of cholesterol in the gastrointestinal (Bertoia et al., 2016). Other studies explain that the administration of alkaloids and isoflavones can reduce body weight, triglycerides, total cholesterol, LDL, and significantly increase HDL levels (Hurt and Wilson., 2012; Adeneye and Crooks., 2015). Chlorogenic acid which is included as phenolic acid can also reduce body weight in obese rats (Wang et al., 2019).

Rats with mangiferin treatment increased body weight lower than brewed Robusta coffee leaves. This is because mangiferin, which belongs to the xantonoid group, can reduce weight, total free fatty acids, and triglyceride levels. Weight loss mainly occurs in fat mass. Mangiferin regulates enzymes in carbohydrate oxidation in muscles and lipid utilization pathways in hepatocytes. Mangiferin also suppresses the lipogenesis enzyme in hepatocytes. This compound can prevent weight gain because of its ability to stimulate the utilization of carbohydrates and fats while inhibiting lipid synthesis (Ekaterina et al., 2016). Mangiferin in this study acted as the standard antioxidant compound.

SOD levels between groups before and after administration of brewed Robusta coffee leaves increased. The administration of brewed Robusta coffee leaves at a dose of $0.36 \mathrm{~g} / 200 \mathrm{~g} \mathrm{BW}$ increased SOD levels in rats higher than the administration of brewed doses of $0.09 \mathrm{~g} / 200 \mathrm{~g} \mathrm{BW}$ and $0.18 \mathrm{~g} / 200 \mathrm{~g} \mathrm{BW}$ of Robusta coffee leaves. This shows that the higher the doses administered, the greater was the increase in the SOD level in rats.

The K1 group was only given a standard diet where the SOD levels in this group experienced an insignificant increase. K2 group was given a standard diet without treatment. SOD levels in this group decreased. Metabolic syndrome results in decreased antioxidant activity in the body, such as SOD and GPx. This is related to the high oxidative stress in sufferers of metabolic syndrome (Baez-Duarte et al., 2016). Cells can maintain a state of reduction-oxidation (redox) when the production of ROS in cells is low or moderate if there is an increase in ROS it will burden antioxidant defenses causing oxidative stress and cell damage. The disruption of redox conditions causes poisoning of cells through the production of peroxidase and free radicals (Bresciani et al., 2015).

Group X1 was given a standard diet and mangiferin. SOD levels in this group experienced a significant increase. Mangiferin is thought to be found in Robusta coffee leaves as found in Arabica coffee leaves content. This compound belongs to the xantonoid group and has a 
strong antioxidant activity because it can scavenge ROS by initiating lipid peroxidation. Mangiferin can neutralize some reactive species and influence the expression and activity of the detoxification enzyme (Fomenko and Chi, 2016). This can reduce oxidative stress and inflammation. These compounds maintain the balance of antioxidant enzymes, such as SOD, GPx, and catalase and can prevent the production of hydroxyl radicals due to the ability of chelating iron in the Fenton reaction. The Fenton reaction involves the production of hydroxyl radicals and the oxidation of $\mathrm{Fe}^{2+}$ to $\mathrm{Fe}^{3+}$. Mangiferin inhibits the Fenton reaction by correlating $\mathrm{Fe}^{2+}$ ions thereby reducing ROS production (Arozal et al., 2015; Gold-Smith et al., 2016)

Group X2, X3 and X4 showed increases in SOD levels. The increase in SOD levels in the three groups was thought to be due to the antioxidant content found in Robusta coffee leaves such as the content contained in Arabica coffee leaves. Robusta coffee leaves contain phenolic content of $27.04 \mu \mathrm{g} / \mathrm{g}$ and flavonoids of 10.90 $\mu \mathrm{g} / \mathrm{g}$. Antioxidant activity in Robusta coffee leaves extract showed inhibition of $79.43 \%$ (Nayeem et al., 2011). Whereas, Arabica coffee leaves contained caffeine content of $7.14 \mathrm{mg} / \mathrm{g}$, chlorogenic acid 21.39 $\mathrm{mg} / \mathrm{g}$, and mangiferin $7.88 \mathrm{mg} / \mathrm{g}$ coffee leaves processed by the JGTP method (Chen et al., 2018).

The antioxidant content in Robusta coffee leaves, in addition to mangiferin, is phenolic. This compound can inhibit oxidation, scavenge free radicals, and act as chelating agents which can stop progressive autooxidative damage. In addition to phenolic, there is flavonoids that can increase SOD levels in rats (Brewer, 2011). This is because flavonoids work as antioxidants that protect the body against ROS. Flavonoids directly scavenge free radicals and act as intracellular antioxidants which can inhibit free radical producing enzymes. Flavonoids stabilize free radicals by reacting to the reactive component of free radicals. High reactivity in the hydroxyl flavonoid group makes the radicals inactive (Banjarnahor and Artanti., 2014; Panche et al., 2016). Research conducted on rats by giving flavonoids with a dose of $100 \mathrm{mg} / \mathrm{kg}$ can increase SOD levels (Luo et al., 2014).

Another antioxidant in coffee leaves is caffeine. Caffeine is a derivative of xanthine which has a role to directly inhibit lipid peroxidation and a high level of inhibition of radical formation (Tellone et al., 2015). This compound can reduce oxidative stress and ROS and protect the antioxidant system (Jeszka-Skowron et al., 2016). Caffeine captures hydroxyl radicals and superoxide by measuring $\mathrm{O}_{2}{ }^{-}$after reacting with caffeine which is measured using electron paramagnetic resonance (Yamagata, 2018).

Other antioxidant compounds in Robusta coffee leaves are chlorogenic acid which acts as an antioxidant by donating hydrogen atoms to reduce free radicals and inhibit oxidation reactions. After donating a hydrogen atom, chlorogenic acid will be oxidized to phenoxyl radicals and stabilized by resonance stabilization (Liang and Kitts, 2016). This compound scavenges ROS resulting from the consumption of a high-fat diet by suppressing the expression of inflammation through inhibition of the protein tyrosine phosphatase 1B, resulting in reduced fat accumulation, weight loss, and reduced risk of insulin resistance (Buscemi et al., 2016; Santana-Gálvez et al., 2017).

\section{Conclusion}

Robusta coffee leaves processed by the Japanese style green tea process contain antioxidants that are useful in the treatment of metabolic syndrome. The administration of brewed Robusta coffee leaves significantly increase SOD levels in metabolic syndrome rats with the most effective dose is $0.36 \mathrm{~g} / 200 \mathrm{~g} \mathrm{BW}$.

\section{Conflict of Interest}

The authors declare no conflict of interest.

\section{Acknowledgments}

This research was supported by Research and Development (RPP) from the Faculty of Medicine, Universitas Diponegoro.

\section{References}

Adeneye, A.A. and Crooks, P.A. (2015). Weight losing, antihyperlipidemic and cardioprotective effects of the alkaloid fraction of Hunteria umbellata seed extract on normal and triton-induced hyperlipidemic rats. Asian Pacific Journal of Tropical Biomedicine, 5(5), 387-394. https://doi.org/10.1016/S2221-1691 (15)30374-9

Arozal, W., Suyatna, F., Juniantito, V., Rosdiana, D., Amurugam, S., Aulia, R., Monayo, E. and Siswandi, R. (2014). The Effects of Mangiferin (Mangifera indica $L$ ) in Doxorubicin-induced Cardiotoxicity in Rats. Drug Research, 65(11), 574-580. https:// doi.org/10.1055/s-0034-1394457

Atmaja, M.I.P., Shabri, Harianto, S., Maulana, H. and Rohdiana, D. (2018). Physical Characteristics of Green Tea Powder Processed by Disc and Stone Mills. Jurnal Teknologi dan Industri Pangan, 29, 77 -84. https://doi.org/10.6066/jtip.2018.29.1.77

Baez-Duarte, B.G., Zamora-Ginez, I., De Jésus, K.L., 
Torres-Rasgado, E., González-Mejía, M.E., Porchia, L., Ruiz-Vivanco, G. and Pérez-Fuentes, R. (2016). Association of the Metabolic Syndrome with Antioxidant Defense and Outstanding Superoxide Dismutase Activity in Mexican Subjects. Metabolic Syndrome and Related Disorders, 14(3), 154-160. https://doi.org/10.1089/met.2015.0088

Banjarnahor, S.D.S. and Artanti, N. (2015). Antioxidant properties of flavonoids. Medical Journal of Indonesia, 23(4), 239-244. https://doi.org/10.13181/ mji.v23i4.1015

Bertoia, M.L., Rimm, E.B., Mukamal, K.J., Hu, F.B., Willett, W.C. and Cassidy, A. (2016). Dietary flavonoid intake and weight maintenance: three prospective cohorts of 124086 US men and women followed for up to 24 years. BMJ, 2016(352), i17. https://doi.org/10.1136/bmj.i17

Bresciani, G., da Cruz, I.B.M. and González-Gallego, J. (2015). Manganese Superoxide Dismutase and Oxidative Stress Modulation. In Makowski, G.S. (Ed.) Advances in Clinical Chemistry., p. 87-130. USA: Elsevier. https://doi.org/10.1016/ bs.acc.2014.11.001

Brewer, M.S. (2011). Natural Antioxidants: Sources, Compounds, Mechanisms of Action, and Potential Applications. Comprehensive Reviews in Food Science and Food Safety, 10(4), 221-247. https:// doi.org/10.1111/j.1541-4337.2011.00156.x

Buscemi, S., Marventano, S., Antoci, M., Cagnetti, A., Castorina, G., Galvano, F., Marranzano, M. and Mistretta, A. (2016). Coffee and metabolic impairment: An updated review of epidemiological studies. NFS Journal, 3, 1-7. https://doi.org/10.1016/ j.nfs.2016.02.001

Chen, X.-M., Ma, Z. and Kitts, D.D. (2018). Effects of processing method and age of leaves on phytochemical profiles and bioactivity of coffee leaves. Food Chemistry, 249, 143-153. https:// doi.org/10.1016/j.foodchem.2017.12.073

Fomenko, E.V. and Chi, Y. (2016). Mangiferin modulation of metabolism and metabolic syndrome. BioFactors, 42(5), 492-503. https://doi.org/10.1002/ biof.1309

Fraulob, J.C., Ogg-Diamantino, R., Fernandes-Santos, C., Aguila, M.B. and Mandarim-de-Lacerda, C.A. (2010). A Mouse Model of Metabolic Syndrome: Insulin Resistance, Fatty Liver and Non-Alcoholic Fatty Pancreas Disease (NAFPD) in C57BL/6 Mice Fed a High Fat Diet. Journal of Clinical Biochemistry and Nutrition, 46(3), 212-223. https:// doi.org/10.3164/jcbn.09-83

Gold-Smith, F., Fernandez, A. and Bishop, K. (2016).
Mangiferin and Cancer: Mechanisms of Action. Nutrients, 8(7), 396. https://doi.org/10.3390/ nu8070396

Guo, H., Gao, X., Ma, R., Liu, J., Ding, Y., Zhang, M., Zhang, J., Mu, L., He, J., Yan, Y., Ma, J., Guo, S. and Wei, S. (2017). Prevalence of Metabolic Syndrome and its Associated Factors among Multiethnic Adults in Rural Areas in Xinjiang, China. Scientific Reports, 7(1), 17643. https:// doi.org/10.1038/s41598-017-17870-5

Hurt, R.T. and Wilson, T. (2012). Geriatric Obesity: Evaluating the Evidence for the Use of Flavonoids to Promote Weight Loss. Journal of Nutrition in Gerontology and Geriatrics, 31(3), 269-289. https:// doi.org/10.1080/21551197.2012.698222

Huyut, Z., Beydemir, Ş. and Gülçin, İ. (2017). Antioxidant and Antiradical Properties of Selected Flavonoids and Phenolic Compounds. Biochemistry Research International, 2017, 1-10. https:// doi.org/10.1155/2017/7616791

Ighodaro, O.M. and Akinloye, O.A. (2018). First line defence antioxidants-superoxide dismutase (SOD), catalase (CAT) and glutathione peroxidase (GPX): Their fundamental role in the entire antioxidant defence grid. Alexandria Journal of Medicine, 54(4), 287-293. https://doi.org/10.1016/j.ajme.2017.09.001

Imran, M., Arshad, M.S., Butt, M.S., Kwon, J.-H., Arshad, M.U. and Sultan, M.T. (2017). Mangiferin: a natural miracle bioactive compound against lifestyle related disorders. Lipids in Health and Disease, 16(1), 84. https://doi.org/10.1186/s12944017-0449-y

Incalza, M.A., D’Oria, R., Natalicchio, A., Perrini, S., Laviola, L. and Giorgino, F. (2018). Oxidative stress and reactive oxygen species in endothelial dysfunction associated with cardiovascular and metabolic diseases. Vascular Pharmacology, 100, 119. https://doi.org/10.1016/j.vph.2017.05.005

Jarukamjorn, K., Jearapong, N., Pimson, C. and Chatuphonprasert, W. (2016). A High-Fat, HighFructose Diet Induces Antioxidant Imbalance and Increases the Risk and Progression of Nonalcoholic Fatty Liver Disease in Mice. Scientifica, 2016, 1-10. https://doi.org/10.1155/2016/5029414

Jeszka-Skowron, M., Sentkowska, A., Pyrzyńska, K. and De Peña, M.P. (2016). Chlorogenic acids, caffeine content and antioxidant properties of green coffee extracts: influence of green coffee bean preparation. European Food Research and Technology, 242(8), 1403-1409. https://doi.org/10.1007/s00217-0162643-y

Jürgens, H., Haass, W., Castañeda, T.R., Schürmann, A., 
Koebnick, C., Dombrowski, F., Otto, B., Nawrocki, A., Scherer, P., Spranger, J., Ristow, M., Joost, H., Havel, P. and Tschöp, M.H. (2005). Consuming Fructose-sweetened Beverages Increases Body Adiposity in Mice. Obesity Research, 13(7), 11461156. https://doi.org/10.1038/oby.2005.136

Kanisius, A. A. (1988). Budidaya Tanaman Kopi. $16^{\text {th }}$ ed. Yogyakarta: Kanisius.

Kaur, J. (2014). A Comprehensive Review on Metabolic Syndrome. Cardiology Research and Practice, 2014, 1-21. https://doi.org/10.1155/2014/943162

Lam, D.W. and LeRoith, D. (2019). Metabolic Syndrome. In Endotext., p. 1-41. Retrieved from https:/www.ncbi.nlm.nih.gov/books/NBK278936/

Liang, N. and Kitts, D.D. (2016). Role of Chlorogenic Acids in Controlling Oxidative and Inflammatory Stress Conditions. Nutrients, 8(16), 1-20.

Luo, A., Peng, P., Fei, W., Yang, L. and Fan, Y. (2014). Isolation and Antioxidant Activity (In Vitro and In Vivo) of The Flavonoid From Tartarian-buckwheat. Journal of Scientific and Innovative Research, 3(2), 168-172.

Marseglia, L., Manti, S., D’Angelo, G., Nicotera, A., Parisi, E., Di Rosa, G., Gitto, E. and Arrigo, T. (2014). Oxidative Stress in Obesity: A Critical Component in Human Diseases. International Journal of Molecular Sciences, 16(1), 378-400. https://doi.org/10.3390/ijms16010378

Mirończuk-Chodakowska, I., Witkowska, A.M. and Zujko, M.E. (2018). Endogenous non-enzymatic antioxidants in the human body. Advances in Medical Sciences, 63(1), 68-78. https:// doi.org/10.1016/j.advms.2017.05.005

Moore, J.X., Chaudhary, N. and Akinyemiju, T. (2017). Metabolic Syndrome Prevalence by Race/Ethnicity and Sex in the United States, National Health and Nutrition Examination Survey, 1988-2012. Preventing Chronic Disease, 14(24), 160287. https:// doi.org/10.5888/pcd14.160287

Nayeem, N., Denny, G. and Mehta, S.K. (2011). Comparative phytochemical analysis, antimicrobial and anti oxidant activity of the methanolic extracts of the leaves of Coffea Arabica and Coffea Robusta. Der Pharmacia Lettre, 3(1), 292-297.

Octavia, Z.F., Djamiatun, K. and Suci, N. (2017). The effect of synbiotic yogurt of tanduk banana fl our in lipid profi le of metabolic syndrome rats. Jurnal Gizi Klinik Indonesia, 13(4), 159-169. https:// doi.org/10.22146/ijcn.19369

Panche, A.N., Diwan, A.D. and Chandra, S.R. (2016). Flavonoids: an overview. Journal of Nutritional Science, 5(47), e47. https://doi.org/10.1017/ jns.2016.41

Purwaningsih, S. (2014). Effect of Infusion Coffee Leaves (Coffea robusta Lind.) on Blood Glucose Level on yhe Mice in Alloxan Induced. Veterinaria Medika, 7(3), 208-215.

Rasyid, R., Sanjaya, W.F. and Zulharmita. (2013). Penetapan Kadar Kofein Daun Kopi Kawa (Coffea Robusta, Lind). Jurnal Farmasi Higea, 5(2), 137143. [In Bahasa Indonesia].

Rochlani, Y., Pothineni, N.V., Kovelamudi, S. and Mehta, J.L. (2017). Metabolic syndrome: pathophysiology, management, and modulation by natural compounds. Therapeutic Advances in Cardiovascular Disease, 11(8), 215-225. https:// doi.org/10.1177/1753944717711379

Saifur Rohman, M., Lukitasari, M., Adi Nugroho, D., Nashi, W., Ida Panca Nugraheini, N. and Wahyu Sardjono, E. (2017). Development of an Experimental Model of Metabolic Syndrome in Sprague Dawley Rat. Research Journal of Life Science, 4(1), 76-86. https://doi.org/10.21776/ ub.rjls.2017.004.01.10

Santana-Gálvez, J., Cisneros-Zevallos, L. and JacoboVelázquez, D. (2017). Chlorogenic Acid: Recent Advances on Its Dual Role as a Food Additive and a Nutraceutical against Metabolic Syndrome. Molecules, 22(3), 358. https://doi.org/10.3390/ molecules 22030358

Shiyan, S., Herlina, Arsela, D. and Latifah, E. (2017). Aktivitas Antidiabetes Ekstrak Etanolik Daun Kopi Robusta (Coffea canephora) Pada Tikus Diabeets Tipe 2 Yang Diberi Diet Lemak Tinggi dan Sukrosa. Jurnal Farmasi Sains Dan Praktis, III(2), 39-46. [In Bahasa Indonesia].

Suhaema. and Masthalina, H. (2015). Pola Konsumsi dengan Terjadinya Sindrom Metabolik di Indonesia (Consumption Patterns with Occurrence of Metabolic SYndrome in Indonesia). Jurnal Kesehatan Masyarakat Nasional, 9(4), 340-347. [In Bahasa Indonesia].

Tellone, E., Galtieri, A., Giardina, B., Russo, A., Bellocco, E., Barreca, D. and Ficarra, S. (2015). Antioxidant Activity of Caffeine. In Preedy, V.R. (Ed.) Coffee in Health and Disease Prevention., p. 835-842. USA: Academic Press. https:// doi.org/10.1016/B978-0-12-409517-5.00092-9

Wang, Z., Lam, K., Hu, J., Ge, S., Zhou, A., Zheng, B., Zeng, S. and Lin, S. (2019). Chlorogenic acid alleviates obesity and modulates gut microbiota in high-fat-fed mice. Food Science and Nutrition, 7(2), 579-588. https://doi.org/10.1002/fsn3.868

Widayati, E. (2012). Oxidasi Biologi, Radikal Bebas, 
dan Antioxidant (Biological Oxidation, Free Radicals, and Antioxidants). Majalah Islam Sultan Agung, 50(128), 26-32.

Wong, S.K., Chin, K.-Y., Suhaimi, F.H., Fairus, A. and Ima-Nirwana, S. (2016). Animal models of metabolic syndrome: a review. Nutrition and Metabolism, 13(1), 65. https://doi.org/10.1186/ s12986-016-0123-9

Yamagata, K. (2018). Do Coffee Polyphenols Have a Preventive Action on Metabolic Syndrome Associated Endothelial Dysfunctions? An Assessment of the Current Evidence. Antioxidants, 7 (2), 26. https://doi.org/10.3390/antiox7020026 